\title{
Fehér András Tibor ${ }^{1 \oplus}$ - Négyesi Imre ${ }^{2 \oplus}$
}

\section{A gépi érzelmek a fegyveres erőknél és az autonóm rendszerekben \\ Mechanical Emotions in the Armed Forces and Autonomous Systems}

\begin{abstract}
Absztrakt
A mesterséges intelligencia terjedésével egyre nagyobb az igény olyan gépekre, amelyek a mostaniaknál „emberibben” képesek müködni. Ehhez elengedhetetlen az érzelmek gépi érzékelése és utánzása. Az alábbiakban elöször bemutatjuk, hogy egy gép mennyiben képes kezelni az érzelmeket, valamint a terület fejlödését és többféle felhasználási lehetöséget a különféle fegyveres erök számára. A szélesebb áttekintést végül a gépi autonómiára szükítjük, ahol bizonyítani igyekszünk hipotéziseinket, miszerint a mesterséges érzelmek alkalmazása lehetövé tenné a gépek erkölcsi érzékének kialakitását, valamint növelné az autonóm rendszerek hatékonyságát.
\end{abstract}

Kulcsszavak: mesterséges intelligencia, gépi érzelemkezelés, gépi etika, gépi autonómia, haditechnika

\section{Abstract}

With the rise of artificial intelligence, there is a growing demand for machines that are able to operate 'more humanly' than they do today. For these, machine sensing and imitation of emotions is essential. Below, we first show the extent to which a machine can handle emotions, as well as the development of the area and its multiple uses for different armed forces. Finally, we narrow the broader review to machine autonomy,

Nemzeti Közszolgálati Egyetem Hadtudományi és Honvédtisztképző Kar, gyakorlati oktató - University of Public Service, Faculty of Military Science and Officer Training, Department of Information Technology, Assistant Lecturer, e-mail: feher.andras@uni-nke.hu

Nemzeti Közszolgálati Egyetem Hadtudományi és Honvédtisztképző Kar, egyetemi docens - University of Public Service, Faculty of Military Science and Officer Training, Department of Information Technology, Associate Professor, e-mail: negyesi.imre@uni-nke.hu 
where we prove our hypotheses that the application of artificial emotions would allow the development of a moral sense of machines as well as increase the efficiency of autonomous systems.

Keywords: artificial intelligence, machine emotion management, machine ethics, machine autonomy, military technology

\section{Bevezető}

Bár technológiáról írunk, mégis emberi dolgok állnak kutatásunk középpontjában. Érzéseink, döntéseink, erkölcsi érzékünk vizsgálatával hagyományosan inkább a humán tudományok művelői foglalkoztak. Ám eredményeiket jó ideje felhasználják a mérnökök és programozók is. Rég közismertté vált, hogy a megfelelő emberi élethez szükség van érzelmi intelligenciára is, nem csupán IQ-ra. A mesterséges intelligencia (MI) „implementációja”, azaz a kivitelezésére, megvalósítására és modellezésére irányuló munkálatok ${ }^{3}$ csaknem 80 éve képezik részét a tudományos kutatásnak, e mellett a gépi érzelemmodellek kutatása is már majdnem 50 éve tart.

Mindennek ellenére a terület, föleg annak fontossága alig ismert, pontosabban eredményeit nem különböztetik meg az MI-fejlesztések eredményeitől. Például a személy felismerése arc alapján az Ml-funkciók körébe tartozik, ám egy arcon a harag jeleinek észrevétele az érzelmeket kutató számítástechnika eredménye. Az érzelmi és az értelmi funkciók azonos alapelven müködnek mind az emberi agyban, mind a gépi neuronhálós implementációban, kutatási szempontból azonban lényegileg térnek el. Az intellektuális és az érzelmi terület távolodása a humán tudományokban az 1980-as években kezdődött meg, elsősorban a többszörösintelligencia-elméletre alapozva. ${ }^{4}$ Az 1990 -es évektöl, az érzelmi intelligencia elkülönített kutatása óta ${ }^{5}$ a különböző pedagógiai és pszichológiai modellek az emberek intellektuális és érzelmi képességeit eltérően kutatják, kezelik és mérik. Ebből következik, hogy az érzelmek gépi reprezentációját sem célszerủ az MI részeként kezelni. A technológia fejlődésével egyre jobban szét is válik ez a két terület, a gépi érzelmek kutatása fokozatosan új tudományággá válik.

Jelen tanulmány egy nagyobb kutatás részeként több célt is kitűzött maga elé. Forráselemzéssel áttekintjük a területet, annak eddigi fejlődését, azokra az eredményekre koncentrálva, amelyeknek katonai, rendészeti vagy nemzetbiztonsági felhasználása elképzelhető. Az így összegyüjtött információkból különféle diszkurzív következtetéseket tudunk levonni. Egyfelöl a technológiák képességeiből az államvédelem területein való felhasználási lehetőségek következnek, így röviden be tudjuk ezeket is mutatni. Másrészt ezekre alapozva tudjuk levezetni hipotéziseink bizonyítását, amelyekre majd kutatásunk további részében támaszkodhatunk.

Az első MI jellegü eredményt 1943-ban publikálták, az első neuronhálós számítógép 1951-ben épült, az MI fogalmát 1956-tól használják. Lásd Stuart Russell - Peter Norvig: Mesterséges Intelligencia modern megközelítésben. Budapest, Panem, 2005. 13.

Howard Gardner: Frames of Mind - The Theory of Multiple Intelligences. New York, Basic Books, 1983.

Kun Bernadette: Az érzelmi intelligencia és az emocionális és szociális kompetenciák szerepe a pszichoaktivszer-használatban. Doktori disszertáció. Budapest, ELTE, 2011. 36. 


\section{A mesterséges érzelem kutatása napjainkig}

A kutatás és a technológia története maga egy külön tanulmányt érdemelne, ezúttal csak rövid összefoglalást adhatunk, amelynek célja csupán világossá tenni a fogalmakat és a technológia lehetőségeit.

\subsection{Előzmények}

A számítógépes kutatások célja kezdetben olyan gépek megalkotása volt, amelyek a lehető legjobban leutánozzák az emberi következtetési képességet. Az érzelmek „gépesítése" jóval később merült fel, elméleti gyökerei azonban hasonlóan messzire nyúlnak vissza. A tudományos világ „humán” felén az 1960-as évekre érett be egy hosszú fejlődés: olyan paradigmaváltás történt az érzelmek kutatásában, amelyet később az elektronika felhasználhatott. Sylvan S. Tomkins amerikai pszichológus és teoretikus affektuselmélete ${ }^{6}$ nem csupán a pszichológiának adott lökést, hanem pár évtizeddel később az informatikának is. Megközelítése szerint az affektus fogalma az érzelmeket kapcsolja össze az érzelmek fizikálisan észlelhetö megjelenésével (például öröm a mosolyban). Ennek lényege, hogy nem tudjuk műszeresen mérni vagy erre szolgáló receptorainkkal közvetlenül érzékelni mások érzelmeit. Csak érzékszerveinken keresztül észleljük azokat, és valójában ezekre az észlelésekre reagálunk (Tomkins kilenc ilyen affektust különböztetett meg). Később a pszichológiában az affektív jelenségek átfedéseiként jelennek meg az „érzelmek” (emotion) és annak konkrét, szubjektív esetei: az érzés (feeling), a hangulat (mood) és az attitüd (attitude). ${ }^{7} \mathrm{Az}$ alábbiakban azonban az „érzelmek” kifejezéssel vagyunk kénytelenek „összefoglalni”, megjeleníteni mindezt, mivel nem célunk az érzelmek, érzések, attitüdök gépi szimulációját külön vizsgálni.

Témánk szempontjából két okból is jelentős Tomkins munkássága. Egyrészt az említett affektuselmélete adta meg a kulcsot a gépi érzelemkezeléshez, hiszen a gépeknek elegendő csupán felismerni az érzelmet kifejező affektust, illetve szimulálni azt az affektust, amelyet egy ember érzéskifejezésnek érzékel. Másrészt ő a script-elmélet megalkotója is, ${ }^{8}$ amely szerint az emberi viselkedés leírható minták és érzelemmintázatok segítségével is. Ebből adódik a gondolkodásminták létezése az emberi megismerésben, és ezek a minták alapvető fontosságúvá váltak az MI-kutatásokban is. Míg a számítástechnika racionalitást hangsúlyozó őskorszakában még úgy vélték, hogy a gépi logika döntéseinek tökéletesítéséhez nagy mennyiségü „alapvető adat” szükséges, az 1980-as éveket követően rájöttek a fejlesztők, hogy a script-elmélet gondolkodásmintáinak segítségével sokkal hatékonyabb MI-modell tervezhetö. Ez a mintaalapú matematikai modell mára jól bevált technológiának bizonyult, sőt a jövőre nézve is joggal füzhetünk hozzá nagy reményeket. Például épp jelen cikk írása

6 Magyarul a "hatáselmélet" kifejezést is használják. Itt az idegen szó megtartása a később bemutatandó affektív számítástechnikával való kapcsolat miatt indokolt. Vö. Silvan S. Tomkins: Affect, imagery, consciousness. New York, Springer, 1962-1963.

7 Lásd Csépe Valéria - Győri Miklós - Ragó Anett: Általános pszichológia. Budapest, Osiris, 2008. Különösen a kötet Nyelv, tudat, gondolkodás c. részfejezete. 290.

8 Bár ezen terület alapmüve tanítványa nevéhez füződik: Donald L. Nathanson: Shame and pride - Affect, Sex, and the Birth of the Self. New York - London, Norton, 1992. 
közben jelentették be a Facebook önfelügyeleten tanuló SEER-algoritmusát, ${ }^{9}$ amely már 84\%-nál is nagyobb pontossággal képes azonosítani képeken látható dolgokat. Az alábbiakban azonban csak az affektuselméletnek a számítástechnikára gyakorolt hatására koncentrálunk.

\subsection{Az affektív számítástechnika fogalma és kezdetei}

Az affective computing szakkifejezés Rosalind W. Picard 1995-ben megjelent cikkéhez kötődik..$^{10}$ Ebben például a Turing-tesztet is elképzelhetetlennek tartja az érzelmek gépi érzékelése és szimulálása nélkül, ${ }^{11}$ továbbá számos később megvalósuló technológiát megjósol, a hordozható számítógépektől (nála affective wearable computers) kezdve egészen a médiafelhasználásokig. A cikk fontosságát leginkább az a szemlélet adja, amely rámutat az érzelmek figyelembevételének fontosságára és figyelembe vehetőségének akkoriban csírázó minden, például fejlesztési, gyártási lehetőségére. Azonban nem ő volt az első, aki ezzel foglalkozott. A korábbi kutatók közül elsősorban Paul Ekman nevét kell kiemelni, aki már 1972-es könyvében tárgyalta szerzőtársaival az érzelmek felismerhetőségét az arcon, feltérképezte az arc izmait, így képes volt ezek mozgásait figyelni és dekódolni, a valódi örömöt az álmosolytól megkülönböztetni. ${ }^{12}$ Az 1990-es évek elején pedig már szóbeli intonáció-13 ${ }^{13}$ vagy kézmozdulat-felismerő"14 modellekre irányuló kutatások is folytak.

Az affective computing egyik rövid magyar meghatározása szerint „érzelmekkel operáló számítástechnika”, ${ }^{15}$ mi azonban inkább az „affektív számítástechnika”, a „gépi érzelem” vagy „mesterséges érzelem” (MÉ) terminusokat használjuk, hiszen főleg az MI-vel összefüggésben, annak bővítményeként vizsgáljuk az MÉ-t. Arra, amikor a két technológiát együtt használjuk, a magyar MÉ2 (esetleg MÉÉ, Mesterséges Értelem és Érzelem) vagy az angol AIAC (Artificial Intelligence and Affective Computing) rövidítést javasoljuk és használjuk, ami rámutat arra, hogy a két oldal külön kezelendő.

Szükséges azonban tovább pontosítani az affective computing (affektív számítástechnika) fogalmat. Az affect (hatás) szó jelen kontextusa egyik nyelvben sem kétirányú kifejezés, pedig az általunk vizsgált szóösszetételben egy oda-vissza hatás jelenik meg. Picard egyaránt affektív számítástechnikának hívja azt, amikor a számítógép emberi érzéseket (input affektusokat) ismer fel, és azt is, amikor érzések (output affektusok) szimulálására képes a komputer. Az affektus tehát egyszerre jelenti az érzékelést

9 A SElf-supERvised = „önfelügyelten tanuló”, de az angolul „látnok" jelentésű szó feltűnése is tudatos nyelvi játék. A rendszer nem emberek által címkézett képekből, hanem az Instagram publikus képei alapján fejlesztette magát ilyen képességűvé. Vö. Priya Goyal et. al.: Self-supervised Pretraining of Visual Features in the Wild. 2021.

10 Rosalind W. Picard: Affective Computing. M.I.T. Media Laboratory Perceptual Computing Section Technical Report, No. 321. 1995.

11 Az eredeti tesztben nem szerepelt ilyen aspektus. Lásd Alan M. Turing: Computing machinery and intelligence. Mind, 59. (1950), 236. 433-460.

12 Újabb kiadásban lásd Paul Ekman: Emotion in the Human Face. Los Altos (California), Malor Books, 2013.

13 lain R. Murray - John L. Arnott: Toward the Simulation of Emotion in Synthetic Speech. A Review of the Literature on Human Vocal Emotion. The Journal of the Acoustical Society of America, 93. (1993), 2. 1993. 1097-1108.

14 Lee Jintae - Tosiyasu L. Kunii: Model-based Analysis of Hand Posture. IEEE Computer Graphics and Applications, 15. (1995), 5. 77-86.

15 Online kézikönyvekben felbukkan az „érzelmi számítások” és az „affektív számítások” kifejezés is. 
és az érzelemkifejezést, így négy géposztály létezhet: csak input (1), csak output (2), mindkettő (3), egyik sem (4). Ezt példázzák napjaink jelentősebb eredményei is: az arcmimikában, a hangban, a kéz- és testmozdulatokban megnyilvánuló érzelmek felismerése és előállítása (3), a szív-, vér-, bőrreakciók fiziológiai formájában megnyilvánuló érzelmek felismerése (1) vagy gépi esztétikai képességek előállítása (2). Jelen tanulmányban is külön kell kezelnünk az input és az output oldalt, mivel jelentősen eltér a hozzájuk szükséges technológia. ${ }^{16}$

Még tovább árnyalva a fogalmat: az affektív számítástechnika olyan, interdiszciplináris fogalom, amely a számítástechnikától a pszichológián át a kognitív tudományokig sok mindent magában foglal. Olyan rendszerek és eszközök tanulmányozását és fejlesztését jelenti, amelyek képesek felismerni, értelmezni, feldolgozni és szimulálni az emberi affektusokat. ${ }^{17}$ A gépi érzelem tehát éppen annyira nem valóságos érzelem, mint amennyire a mesterséges intelligencia nem bölcsesség. Napjainkban az affektív számítástechnika jelentésének szükülése figyelhető meg, néhol csak az MI-t használó technológiára értik, vagy az input oldalra korlátozzák.

\subsection{Az érzelemmotortól a mesterséges empátiáig}

Az affektív számítástechnika egyik első reprezentánsa egy output-osztályú gép volt a kétezres évek elején: a PlayStation-2 játékkonzol chipjében „érzelemmotor"-nak (Emotion Engine, EE) nevezték el azt a technológiát, amely a 3D játékgrafikát megvalósította. ${ }^{18}$ Nem pontos a szóhasználat, hiszen a technológia lényege a gyorsabb és jobb grafikai ábrázolás volt, nem kifejezetten az érzelmek kifejezése - igaz, a szereplők arcán ez által vált lehetővé érzelmek ábrázolása is. A neuronhálós megközelítés helyett akkoriban egy speciális skalárvektor-architektúra is elegendő volt a korábbinál szebb grafikára, egészen 2012-ig gyártották a különféle EE-chipeket. (Jogos lenne ennek mintájára a mai, még finomabb érzelemkifejezésre alkalmas szoftvereket, sokmagos videókártyákat és egyéb eszközöket is az affektív számítástechnikához sorolni, hiszen az affektusokra irányuló kutatásokat használják fel.) Ezzel párhuzamosan az évezred elejétől számos ígéretes projekt zajlott az érzések gépi analizálására vagy előállítására (például a mimika, kézmozdulatok, testbeszéd vagy a hang felismerésére, vagy érzelmes hang, érzelmeket kifejező arcok megjelenítésére), amint arról egy 2005-ös nemzetközi konferencia is tanúskodik. ${ }^{19}$

Sok kutató használt már Ml-modelleket ilyen célokra. Ám a megfelelő affektus-adatbázisok hiánya és az MI-modelleket támogató hardverek elégtelensége ekkor még sok ötletet a szakmán belül tartott, illetve csak felhő alapon volt lehetőség az MI elfogadható minőségű használatára. A 2005-ös, főleg MI-alapú Google Talk még kicsit géphangon beszélt. Lassan csiszolódott ki olyan MÉ-felhő, amelynek angol nyelvű

16 Felmerült ezen fogalmak magyarosítási lehetősége, ám pl. a „bemeneti érzés kifejeződése” nehézkes, az „inputhatás” pedig pontatlan. Ezért az angol szó fonetikus átírása tủnik a legcélravezetőbbnek.

17 Pat Research: What is Affective computing? Top 15 Affective Computing Companies. 2020.

18 Atsushi Kunimatsu et al.: Vector unit architecture for emotion synthesis. IEEE Micro, 20. (2000), 2. 40-47.

19 Jianhua Tao - Tieniu Tan - Rosalind W. Picard (szerk.): Affective Computing and Intelligent Interaction. $1^{\text {st }}$ international conference. Peking, 2005. 
beszéde élethűnek mondható (például az Amazon Echo/ Alexa 2014, a WaveNet 2016), és még a kortárs megoldások sem tökéletesek ezen a téren.

A beszélő gépek példáján egyben rávilágíthatunk arra a sajátosságra, amelyet fontos kiemelni az MÉ fejlődésének áttekintésekor: sok esetben elmosódnak az affektív számítástechnika határai. Ha beszédet fejlesztenek, annak kifejezőkészségéért és nyelvhelyességért az MI-modulok felelősek, de az élethü, érzelmes hanglejtésért az MÉ. Ezek együtt, egyszerre teszik értelmi és érzelmi szempontból valósághűvé a gépi érzelmet (itt a hangelőállítást). A 2005 utáni korszakra jellemző még, hogy az audio- vagy videószenzorok megújulásán túl teljesen újszerủ érzékelők sora jelenik meg: kezdve a Nintendo cég Wii mozgásérzékelő játékkonzoljától (2006), ${ }^{20}$ a fizikálisan kapcsolódó szenzorokkal végrehajtott érzelemfelismerésen át (szemkövető szemüvegek, EEG-távirányítók ${ }^{21}$ ) egészen a mikrohullámú testradarokig (lásd 2.4.).

A játékok mellett az érzelemfelismerők húzóágazatává kezd válni például az autóipar is, ${ }^{22}$ de a katonai kutatások szintén segítik a terület fejlődését. Ezek közül azt a török katonai kutatást szeretnénk röviden bemutatni, ${ }^{23}$ amely már 2009-ben a hagyományos neuronháló érzelmi bővítését vetette fel. A modellbe a célpontfelismerési képességek javítására két érzelmet is felvettek: a szorongást és a magabiztosságot. Dr. Khashman kutatócsoportja abból az emberekre jellemző tényből indult ki, hogy amikor új feladatot tanulunk, szorongásunk szintje magas, a magabiztosságunk pedig a tanulás kezdetén alacsony, ám idővel, a tanulás és pozitív visszajelzések által a szorongásszintünk csökken, míg a magabiztossági szintünk nő. Így hozhatunk a tanulás révén jobb döntéseket, mégpedig rövidebb idő alatt. A modell beváltotta a reményeket, a tesztek alapján a szorongási és magabiztossági együttható beépítése a rendszert hatékonyabbá tette a katonai célok azonosításában, egyben gyorsabbá a tanulás és a döntéshozatali idők szempontjából Ez a modell példa arra is, hogy az egyes érzelemmodellek nem emberibbé teszik a rendszert, csupán hatékonyabbá válik alkalmazásukkal a hagyományos MI.

Végül Minoru Asada nevét szeretnénk kiemelni, aki már 2001-től a gépi érzelemmel kapcsolatos témákkal foglalkozott, és egy 2012-es tanulmányában vezette be a mesterséges empátia kifejezést, ${ }^{24}$ amely azóta igen széles vizsgálati területté nőtte ki magát. A szerteágazó kutatások középpontjában az áll, hogy egy gép (robot) egy adott emberi érzelemre a megfelelő érzelemmel válaszoljon (input-output modell). ${ }^{25}$

20 Ez egy kézben tartható, de vezeték nélküli alkatrész (remote) mozgását detektálta infravörös érzékelővel.

21 Elektro-enkefalográfiás fejérzékelő: nem hagyományos effektust érzékel, hanem elektrofiziológiai változásokat, idegsejtek elektromos aktivitását méri valós időben.

22 Ez már 2005-ben prognosztizálható volt olyan ötletekkel együtt, mint a csoportdöntési segédeszközként való használat vezetők számára, hogy feltérképezhessék a beosztott állományuk hangulatát. Lásd Joseph Bullington: 'Affective' Computing and Emotion Recognition Systems. Information Security Curriculum Development Conference, Kennesaw, 2005. 97.

23 Adnan Khashman: Emotional System for Military Target Identification Prof. NATO Research and Technology Organisation Symposium on Information Management-Exploitation, Stockholm, 2009.

24 Minoru Asada: Development of artificial empathy. Neuroscience Research, 90. (2015), 41-50.

25 Erre külön tanulmányban tervezünk majd kitérni. 


\subsection{Jelen és közeljövő: érzelemchip és affektusradar}

Az EmoShape nevü kis cég innovációja messze nagyobb távlatokat nyit meg, mint az affektív számítástechnikai piac más, akár sokkal nagyobb cégeinek tevékenysége. 2015-ben jelentettek meg egy EPU-chipet, vagyis egy Érzelmi Feldolgozó Egység ${ }^{26}$ névre hallgató technológiát, ennek ma kapható EPU-III (2017) verzióját ismertetjük. Több szempontból rugalmas technológiáról van szó, mivel egyrészt többféle kiadása létezik, ${ }^{27}$ egy felhőalapú szolgáltatás, és egy beszerelhető mikrochip, amit eMCUnak ${ }^{28}$ hív a cég. Másrészt forgalmazzák USB-csatlakozású perifériaként is, sőt mivel a hozzá tartozó szoftverfejlesztő készlet és dokumentáció megvásárolható, ezáltal bárki kibővítheti saját szolgáltatásait érzelmi összetevőkkel. Rugalmassága mellett az érzelemkezelés eddigieknél sokkal nagyobb pontossága, valamint az input- és outputképességek együttes jelenléte teszi diszruptívvá a fejlesztést. ${ }^{29}$

Az EPU egyrészt képessé tesz egy gépet arra, hogy érzelmileg megértse, amit olvasnak neki vagy amit lát, másrészt érzelmi állapotokat és szintetikus érzelmeket hoz létre az intelligens gépekben. A projekt a 2.2 fejezetben tárgyalt Ekman-féle kutatásokat viszi tovább. Számtalan elmélet létezik az alapérzelmek csoportosítására, ${ }^{30}$ ezek közül az EPU a következő 12 alapérzelemre redukált sémával müködik: a düh, félelem, szomorúság, undor, közöny, megbánás, meglepetés, előérzet, bizalom (remény), önbizalom, vágy és öröm. ${ }^{31}$ Ezen érzelmek különböző intenzitású összeadódásaiból áll elő az a mátrix, amely az EPU érzelmi spektrumát képezi. Így kell érteni a 64 billió érzelmet, amit a rendszer azonosítani képes és amelyekből reakcióját előállítja, ${ }^{32}$ ezáltal biztosítva nagy teljesítményủ érzelemtudatot a számítógépek vagy robotok számára. Ráadásul, mivel kommunikálni is képes más mesterségesintelligencia-technológiákkal, így 98\%-os pontosságot képes elérni egy beszélgetés során, sőt lehetővé teszi az MI és a robotok spontán (nem programozott) nevetését vagy sírását és ezek megértését. A jövőben az élethüen beszélgető gépek létrehozása a cél, amihez NLG-algoritmusokat ${ }^{33}$ és az említett WaveNet technológiát kombinálnák saját termékükkel.

Mivel a pusztán vizuális alapú érzelmeket felismerő rendszerek becsaphatók (hiszen az álmimikát könnyebb megtanulni, mint a szív- és légzésrendszer rezdüléseit uralni), a cég kifejlesztett egy aRadar (affektus-Radar) névre hallgató szenzort is, amely vezeték nélküli (mikrohullámú) technológiával érzékeli az ember légzésének

26 Emotion Processing Unit - fordításunkkal az eszköz kettős (érzelmi input és output) funkcióját is érzékeltetni akartuk.

EmoShape Confidental: Emotion Processing Unit III Brochure.

28 Emotional Micro Controller Unit (érzelmi mikrovezérlő), ami a számítástechnika azon korszakára utal, amikor még különböző mikrovezérlők (MCU-k) voltak szükségesek a CPU mellé, különböző vezérlési feladatok ellátására, amelyek később beleolvadtak a CPU-ba.

29 A „diszruptív technológia" (értsd: az addigi megoldásokat "felforgató” innováció) kifejezés hazánkban inkább csak gazdasági vonatkozásban ismert, pedig egy 1995-ös cikk már bevezette. Lásd Joseph Bower - Clayton Christensen: Disruptive technologies. Catching the Wave. Long Range Planning, 28. (1995), 2. 155.

30 A szakirodalom szerint a félelmet, a dühöt, az undort, a szomorúságot, az örömöt, a meglepődést és az érdeklődést a legtöbben alapérzelemnek tekintik. Ezek közül hat szerepel az EPU-ben. További csoportosítások: Csépe-Győri-Ragó (2008): i. m. 293

31 Az angol kifejezések: anger, fear, sadness, disgust, indifference, regret, surprise, anticipation, trust, confidence, desire, joy.

32 EmoShape Confidental i. m.

33 Natural language generation = természetes nyelv generálása. Az adatok értelmes szöveggé alakításának kérdéséhez lásd Dan Woods: Why Big Data Needs Natural Language Generation to Work. Forbes, 2015. július 9. 
és szívverésének pontos hullámformáit (egy EKG-készülékhez hasonlóan). Ez a szenzor kiegészittheti, pontosithatja az EPU-chip által vizuális affektusok segítségével felismert érzelmek meghatározását. Az aRadar és az EPU-technológiát együttes használatát az okosautók következő generációjában (ExoCar néven) és számítógépes játékokban vélik hasznosíthatónak, de kézenfekvő a rendészeti felhasználása is, amire alább rátérünk. Magát az EPU-t pedig az következő fejezetben található lista szinte minden részében hasznosítani lehet.

\section{A gépi érzelmek katonai alkalmazási lehetőségei röviden}

Számos olyan MÉ-fejlesztés zajlik, amelynek terjedése inkább céges környezetben várható $^{34}$-az ügyfélkezelés érzelmet kifejező chatbotjaitól ${ }^{35}$ a szórakoztatóipari és kényelmi felhasználási módokig. Ezeket a civil alkalmazásokat is megvásárolhatják a fegyveres erők - például a számítógépes játékok érzelmi képességei jól szolgálhatják a komfortérzet növelését a pihenőidő eltöltése során -, ám ez nem nevezhető sajátosan katonai vagy rendészeti alkalmazásnak. Sokféle sajátos alkalmazási lehetősége kínálkozik az MÉ képességeinek kiaknázására a fegyveres erők és az állami hivatalok számára. Ahogyan az MI katonai alkalmazása a technológia megjelenése után nem sokkal kutatások tárgya lett, úgy az MÉ katonai felhasználása is már akkor felmerült, amikor még kevéssé volt ismert a technológia. 2004-ben a DARPA már „nem invazív érzelemfelismerő rendszer [...] kifejlesztésére szólít fel, amely alkalmas katonai / operatív környezetben vagy olyan környezetben történő telepítésre, amelyben az ellenség lehetséges fenyegetéseinek diszkrét megfigyelése kívánatos". ${ }^{36}$ Ez az érdeklődés napjainkig kíséri a fejlesztéseket, megjelenik a NATO 2020-as fejlesztési tervében is, ${ }^{37}$ de még ekkor is csak az érzeleminput kerül fókuszba, érdekes módon az érzelemoutput alkalmazhatóságának vizsgálatát nem említi a DARPA 2020-as költségvetése sem. ${ }^{38}$ Konkrét felhasználási módok az idézett forrásokban nem találhatók, ezért magunk állítottunk össze néhány példát, amelyek sorrendje a kevésbé lényegesek felöl a fontosabbak irányába halad. A lista célja nem a felhasználási paletta teljességének bemutatása, csupán a lehetőségek sokszínűségének felvillantása (ezeket az olvasó továbbgondolhatja):

1. A kiképzés területén föleg a már meglévő MI-alapú, esetleg VR-technológiával megoldott szimulációknak adhat szárnyakat. Ha a szimulátor érzékeli a résztvevők érzelmeit, az egyrészt felhívhatja a kiképző figyelmét olyan lappangó, enyhe fóbiákra, vagy problémakezelési zavarokra, amelyek éles helyzetben nagy

34 Egy rövid, tömör felsorolást ad pl. Dilmegani Cem: 24 Affective Computing (Emotion Al) Applications / Use Cases.

35 Stephan Diederich et al.: Emulating Empathetic Behavior in Online Service Encounters with Sentiment-Adaptive Responses. Insights from an Experiment with a Conversational Agent. ICIS 2019 Proceedings, 2019.

36 DARPA (Defense Advanced Research Projects Agency - Fejlett Védelmi Kutatási Projektek Ügynöksége) SB032-038, 2004. Számos publikációban idézik ezt a helyet, de az azokban megadott forrás már nem él, a dokumentum nem fellelhető. Az idézet forrása: Bullington (2005): i. m. 96.

37 Dale. F. Reding - Jacqueline Eaton: NATO ST Trends Report 2020-2040, Exploring the SETEdge. Brussels, NATO Science \& Technology Organization, 2020. 52, 58.

38 Defense Advanced Research Projects Agency: Department of Defense Fiscal Year (FY) 2020 Budget Estimates. Washington, Defense Advanced Research Projects Agency, 2019. 
kárt okozva, váratlanul jelennének meg. Másrészt, egy output MÉ-vel is ellátott program képes lehet figyelembe venni a rossz beidegződéseket és félelmeket, így azoknak megfelelően tudja folytatni a szimulációt (akár úgy, hogy ezeket elkerüli, akár úgy, hogy kifejezetten hasonló problémákat és félelmeket generál). Harmadrészt, ha a szimulált arcok, emberi hangok, elhangzó megfogalmazások érzelmeket közvetítenének, úgy bizonyos pszichológiai müveletekre is hatékonyabb (átérzett) felkészülést tesz lehetővé. Végül megemlíthető, hogy akár a napjainkban felértékelődött távoktatási feladatoknál is hasznos, ha az oktató automatikus visszajelzést kaphat az MÉ-szenzor által arról, hogy a hallgatók mennyire követik az anyagot, azt mennyire tartják megfelelőnek.

2. Az egészségügyi gyakorlatban számos területen fontosak a tünetek kifejeződései (affektusai): az arckifejezések, az izomfeszültség, a testtartás, a kézés vállmozdulatok, a beszédminták, a szívverés, légzés, a pupilla kitágulása, a testhőmérséklet. ${ }^{39}$ Bevetés támogatásához egy szemüvegbe integrált szenzor és például egy EPU-stick segítheti a diagnózist orvos nélküli helyzetben is, de ilyen helyzetekben egy testszenzoros rendszer elemző moduljaként is hatékonyan alkalmazható MÉ. E mellett kifejezetten katonai lelki betegségek (poszttraumás stressz, szerzett fóbiák) kezelésére jó ideje alkalmazzák a hagyományos MI-t - ami MÉ-vel bővítve, pontosan érzékelni képes a páciens érzelmi reakcióját, vagy készülő pánikrohamát kezelés során. A kezelés elsősorban a virtuális világok előállítására épül - itt a rendszer reakcióját is meghatározhatja az MÉ, az előző pontban leírt szimulációhoz hasonlóan.

3. Nemzetbiztonsági használatában a csoportos hangulatmérés-elemzés során alkalmazható az MÉ. Hasznos lehet mind a saját állomány hangulatának (kimerültségének vagy lelkességének) elemzésére, mind pedig a civil lakosság reflexiómérése. Ez utóbbira egy megvalósult példa az Arab Emírségek egy érdekes fejlesztése. Egy érzéselemző térfigyelő rendszer telepítésétől és használatától várják állampolgáraik hangulatának jobb megértését, amit az állam döntéseinél figyelembe vehetnek. ${ }^{40}$ (Jogi aggályok kezelési módjáról nem szól hír.)

4. Rendészeti területen kihallgatások során egészen bizonyos, hogy tíz éven belül (beszerzési ártól függően) felválthatja a hagyományos hazugságvizsgáló berendezéseket az MÉ-alapú kikérdezéstámogatás. Akár a vizuális érzelemelemzési módszerek, vagy például az említett aRadar évről évre árnyaltabb képet ad a kihallgatott személyről (szorong, dühös, titkol valamit stb.). További előnye, hogy a vizsgálat rejtve is elvégezhető - miután leküzdötték ennek nyilvánvaló jogi problémáit.

5. Titkosszolgálati vagy terrorelhárítási célú használatnál az automatikus célpontazonosítás eddiginél hatékonyabb megoldásait valósíthatja meg az MÉ. Például fokozottan biztosítandó helyszínen (fontos állami hivatal, bank) vagy kiemelt rendezvényeken segíthet kiszürni a gyanús viselkedést a már említett

39 Shaundra B. Daily et al.: Chapter 9 - Affective Computing. Historical Foundations, Current Applications, and Future Trends. In Myounghoon Jeon (szerk.): Emotions and Affect in Human Factors and Human-Computer Interaction. Cambridge, Academic Press, 2017. 213-231.

40 Index Holding: Empath in UAE to Measure Happiness. 2018. 
videójel- (arc-, testbeszéd-) elemzés és egyéb szenzoradatok segítségével. Mivel a rendszer sok érzékelő adatait egyszerre, összefüggést keresve tudja analizálni, képes lehet olyan csoportos összehangolt tevékenységre következtetni, amit ember nem vehet észre. ${ }^{41}$

6. A kibervédelmi és kibertéri támadó számítógéprendszerek is hatékonyan használhatnak input és output MÉ-t egyaránt, elsősorban olyan sérülékenységvizsgálatnál, ahol az emberi gyengeséget szeretnék támadásra kihasználni vagy a védelemnél figyelembe venni. Az érzelemanalízist az említett emberi gyengeségek szimulációi során tudja egy rendszer jól alkalmazni, így az emberi tényezőből eredő kibertéri kockázatokat képes veszélyességi sorrendbe rendezni. Kibervédelmi oldalról ez azt jelenti, hogy az ilyen kockázatelemzés alapján sokkal árnyaltabban szabhatók meg az alkalmazandó ellenlépések. A kibertámadások oldaláról pedig hozzásegít a célrendszer legérzékenyebb biztonsági réseinek megtalálásához. ${ }^{42}$

7. Döntéstámogató és döntéshozó rendszerekben az MÉ alkalmazása elkerülhetetlen lesz, mivel csak ez által lehetnek a rendszernek erkölcsi képességei. Ennek részleges kifejtését jelen tanulmányunk következő fejezetében végezzük el.

\section{A mesterséges érzelem jelentősége a gépi döntésekben}

Itt érkeztünk el az absztraktban említett hipotéziseinkhez, amelyeket nem technológiai, inkább filozófiai oldalról lehet bizonyítani. Annak igazolását, hogy „a mesterséges érzelmek alkalmazása lehetővé tenné a gépek erkölcsi érzékének kialakítását" arra a felismerésre alapozzuk, hogy az emberek a döntéseiket nem a rideg logika alapján hozzák meg, hanem az értelmi-érzelmi képességeik egésze vesz részt a döntésben. ${ }^{43}$ Söt, az emberek nem csupán a konkrét döntéseket, hanem az elvont elvi megközelítéseiket sem kizárólag értelmi síkon alakítják ki, vagyis az életszemlélet kialakulásában is részt vesz az érzelmi oldalunk (valakinél meghatározó mértékben, másoknál kevésbé, adottságoktól függően). Így az érzelmek közvetlenül és közvetetten is szerepet kapnak abban, amikor erkölcsi alapon kell lehetőségeket mérlegelni, prioritásokat összevetni, a legkisebb rosszat megtalálni és döntést hozni. Más szóval az érzelmi intelligenciától is nagyban függ, hogy képes-e valaki erkölcsösen dönteni. ${ }^{44}$

Abból a felfogásból indulunk ki, hogy az érzelmi oldalunk is része annak, ami az állatok fölé emel minket. Nem csupán intellektualitásunk fejlettebb nagyságrendekkel az állatvilágban fellelhető problémamegoldó képességeknél, de érzelmeink is sokkal árnyaltabbak. A kettő együttléte és ennek eredője az, ami az emberi mivoltunk (emberségünk vagy inkább emberségességünk) alapja. Hiába szeretnénk egy MI-t megtanítani arra, hogy bonyolult és emberileg átláthatatlan döntéseket hozhasson,

\footnotetext{
Ezzel kapcsolatban a megfigyelhetőség jogszerüségén túl a rendszer tévedésének esetei is felvetnek jogi problémákat.

42 Fehér András - Négyesi Imre: Artificial Intelligence in Cyberspace I. Al based Cyber-attack Capabilities. RED-American Journal Of Research Education And Development, 2. (2019), 31-45.

43 Alapos összefoglaló mủ e tárgyban: Keith Oatley - Jennifer M. Jenkins: Érzelmeink. Budapest, Osiris, 2001.

44 Nisha Agarwal - Nidhi Chaudhary: Role of Emotional Intelligence in Ethical Decision Making. International Journal of Management \& Business Studies, 1. (2013), 3. 28-30.
} 
mivel a tényezők bonyolultsága erkölcsileg is egyre nagyobb összetettséget jelent. Az előbbiek szerint viszont az erkölcsi szinthez nem elegendő a puszta logika. Hiába szimuláljuk az emberi értelmet, a csak az alapján hozott döntés nem lesz „emberséges”, a rendszernek szüksége lesz az emberi érzelmek gépi leképezésére is.

Ráadásul, így a gép döntései nem csupán közelebb állnak majd az emberi döntésekhez, hanem még a rendszer hatékonysága (a döntés gyorsasága) is javul, amint azt második hipotézisünk elővételezi. Ennek igazolását az érzelmek döntésbeli fontosságára alapozzuk. Jelenleg ugyanis az egyik legnagyobb gondot az okozza a mesterséges döntések meghozatalában, hogy a rendszer hajlamos túl hosszú ideig „gondolkodni" a döntésen, és ez a döntéshalogatás tragédiához is vezethet. ${ }^{45}$ Ilyen esetekben egy emberi elme sem lenne képes tökéletes és egyben villámgyors döntésre, viszont egy ember, ha szükséges, képes önmagában felülírni a tökéletes döntésre való törekvést. Egy katona vagy rendőr egy bevetésen, vagy egy sofőr egy hirtelen forgalmi szituációban képes gyors döntést hozni, „ráérezve”, hogy mit kell tenni, és hogy a halogatás a legrosszabb, amit tehet. Az emberek is gyakorlási-tanulási folyamatok során sajátítják el, azt a középutat, hogy ne hamarkodják el a döntést, ha van idejük átgondolni a helyzetet, de ne halogassanak, ha a másodpercek életekbe kerülhetnek. Az emberi döntések érzelmi paramétereinek egy része az illető aktuális érzelmi kiegyensúlyozottságának is függvénye. Ezt a hátráltató tényezőt egy gépi döntés érzelmi moduljából ki lehet és ki kell hagyni. (Hasznosan lehet azonban alkalmazni például eseményszimulátorokban, hogy a fáradékonyságot [és az ebből adódó türelmetlenséget, agressziót stb.) élethüen tudjuk figyelembe venni]. Tehát, ha a döntéshozó gépek mindig egy kiegyensúlyozott személy érzelmi állapotát szimulálják, úgy hátrányok nélküli hatékonyságjavulást érhetünk el. Ugyanis az MÉ segítségével sokkal jobban skálázhatók a váratlan helyzetekre adandó automatikus reakciók, például a „meglepetés" érzésének beiktatásával: ha a gép „nagy meglepetést érez” akkor egy erősen leszűkített döntéshalmazból villámgyorsan dönthet.

Hipotéziseink igazolása után azonban nem mehetünk el szó nélkül emberi mivoltunk negatív oldalai mellett sem (mint például az önzés, a hatalomvágy, kapzsiság, gőg, düh, bosszúvágy stb.). Nem azt hívjuk „emberség”-nek, ami ilyen tulajdonságokból táplálkozik, ${ }^{46}$ és hogy az ember igazából nem az érzelmei miatt választja a rosszat, hanem az ego-alapú ösztönei miatt (könnyen „maga felé hajlik a keze”). Emberi nagyságnak azt tartjuk, amikor valaki képes saját, ösztönös érdekei és szempontjai fölé emelkedni. Miközben az MI az értelmünkkel, az MÉ érzelemvilágunkkal hozható analógiába, ösztöneinknek is van gépi megfelelője: az a hagyományos program, ami nem tanulás által alakul ki, hívjuk most alapprogramnak. Mi emberek, „állati” ösztöneinket értelmi-érzelmi képességeink által haladhatjuk meg, ezek segítségével uralkodhatunk rajtuk. Tanulással fejlesztjük őket olyan szintre, hogy képesek legyünk egyes ösztöneink ellen, erkölcsösen vagy hösiesen cselekedni. Mennyivel könnyebb olyan biztonságos, erkölcsös érzelmeket szimulálni, amiben a gép „érzelmeinek" nem is kell saját önző alapösztönei ellen dolgoznia, mivel alapprogramjukat („ösztöneiket") eleve önzetlenségre terveztük! Vagyis az említett negatív oldalak egy okosan

45 Fülöp Norbert Attila: Az önvezető autók első gyalogos áldozata. Alapjárat, 2018. március 20.

46 A klasszikus meghatározás a megértés, jóindulat, tisztesség stb. szavakhoz kapcsolja. Lásd Bárczi Géza Országh László (szerk.): A magyar nyelv értelmezö szótára. Budapest, Akadémiai, 1959-1962. 
tervezett és tanított gépnél eleve kihagyhatók, megtartva az értelem-érzelem kettős hatékonyságát.

Ezzel még számos probléma nyitva maradt, itt csupán a téma megértéséhez is elkerülhetetlen elveket akartuk felvetni, de a kiegyensúlyozottságon és önzetlenségen túl szükséges egy sor új alapelvvel kiegészíteni az Ml-fejlesztések eddigi szabályozását. ${ }^{47}$ Ezekre az államilag vagy nemzetközileg betartatandó, az MÉ2 biztonságos fejlesztéséhez és használatához szükséges szabályokra összeállított javaslataink egy másik tanulmány részét képezik majd.

Végül tanulságos megvizsgálnunk, hogy milyen arányban lesz szükséges keverni az MI- és MÉ-képességeket egy döntéshozó rendszerben. Mivel ez az arány az emberi döntéshozatalban sem világos, sőt müszerekkel nem is mérhető, a válasz csak hoszszas kísérletek eredményeképpen adható meg. Ezen a ponton azonban eljátszhatunk a gondolattal, hogy ha végre meghatározható lesz ez az ismeretlen arány, valószínúleg pozitívan fog majd visszahatni az emberi viselkedéstanra és az erkölcs elméleteire. Tehát nem csupán kényelmet növelő technológiát fejlesztünk, hanem ezzel együtt emberségességünk fejlesztéséhez is fogódzókat kaphatunk, amelyek az önismereti tréningektől az új pedagógiai metodológiákig használhatók lesznek.

\section{Következtetések}

A fenti elemzéssel remélhetőleg sikerült világossá tenni, hogy az MÉ2 elöretörésével paradigmaváltás áll a küszöbön. Az ilyen gépek hatékony munkatársaink lehetnek, de mint minden dolog, felhasználhatók rossz célokra vagy felelőtlenül is. A hangsúlyt most a gépi erkölcsi érzék és az MÉ szoros kapcsolatának kimutatására kívántuk helyezni, hiszen az azokra épülő gépi autonómia lehetőségei lehetnek a jövő legdiszruptívabb (lásd 30. lábjegyzet) innovációi. Kirajzolódott, hogy az MÉ inputképességeinek kutatása és fejlesztése jóval előbbre jár, de a katonai és rendészeti felhasználás szempontjából inkább az outputképességekkel is rendelkező fejlesztések érdekesek. Összességében tehát az MÉ-technológiának számos előnyös hozadéka várható. Az MÉ a már meglévő MI-felhasználásokat hatékonyabbá teheti és adaptálható katonai-rendészeti felhasználásokra is, valamint ez lehet a kulcsa az autonóm fegyverrendszerek elfogadásának is, ami ellen erős nemzetközi tiltakozás tapasztalható, mivel az MÉ által ezek erkölcsösebben müködhetnek. A leírtak persze számos jogi problémát is felvetnek azokon túl, amit említettünk - ezek megfelelő tisztázása nélkül a technológia veszélyessé vagy használhatatlanná válik.

\section{Felhasznált irodalom}

Adnan Khashman: Emotional System for Military Target Identification Prof, NATO Research and Technology Organisation Symposium on Information Management-Exploitation,

\footnotetext{
Az eddigi szabályozásról lásd Négyesi Imre: A mesterséges intelligencia katonai felhasználásának társadalmi kérdései. Honvédségi Szemle, 149. (2021), 1. 133-144.
} 
Stockholm, 2009. Online: www.semanticscholar.org/paper/Emotional-System-forMilitary-Target-Identification-Khashman/598e392add0580da30ae50559e8361df27e34d0d

Agarwal, Nisha - Nidhi Chaudhary: Role of Emotional Intelligence in Ethical Decision Making. International Journal of Management E Business Studies, 1. (2013), 3. 28-30. Online: www.ijmbs.com/31/nisha.pdf

Asada, Minoru: Development of Artificial Empathy. Neuroscience Research, 90. (2015), 41-50. Online: https://doi.org/10.1016/j.neures.2014.12.002

Bárczi Géza - Országh László (szerk.): A magyar nyelv értelmező szótára. Budapest, Akadémiai, 1959-1962.

Bower, Joseph - Clayton Christensen: Disruptive Technologies. Catching the wave. Long Range Planning, 28. (1995), 2. 155. Online: https://doi.org/10.1016/00246301(95)91075-1

Bullington, Joseph: 'Affective' computing and emotion recognition systems. Kennesaw, Information Security Curriculum Development Conference, 2005. 95-99. Online: https://doi.org/10.1145/1107622.1107644

Cem, Dilmegani: 24 Affective Computing (Emotion Al) Applications / Use Cases. Online: https://research.aimultiple.com/affective-computing-applications/

Csépe Valéria - Győri Miklós - Ragó Anett: Általános pszichológia 3. Nyelv, tudat, gondolkodás. Budapest, Osiris, 2008.

Daily, Shaundra B. - Melva T. James - David Cherry - John J. Porter - Shelby S. Darnell - Joseph Isaac - Tania Roy: Chapter 9 - Affective Computing. Historical Foundations, Current Applications, and Future Trends. In Myounghoon Jeon (szerk.): Emotions and Affect in Human Factors and Human-Computer Interaction. Cambridge, Academic Press, 2017. 213-231. Online: https://doi.org/10.1016/ B978-0-12-801851-4.00009-4

Defense Advanced Research Projects Agency: Department of Defense Fiscal Year (FY) 2020 Budget Estimates. Washington, Defense Advanced Research Projects Agency, 2019.

Diederich, Stephan - Max Janssen-Müller - ALfred Benedikt Brendel - Stefan Morana: Emulating Empathetic Behavior in Online Service Encounters with SentimentAdaptive Responses. Insights from an Experiment with a Conversational Agent. ICIS 2019 Proceedings, 2019. Online: https://aisel.aisnet.org/icis2019/smart_service_ science/smart_service_science/2

Ekman, Paul: Emotion in the Human Face. Los Altos, California, Malor Books, 2013. EmoShape Confidental: Emotion Processing Unit III Brochure. EmoShape Inc., 2018. Online: https://emoshape.com/wp-content/uploads/2019/04/EPU-III-Brochure.pdf

Fehér András Tibor - Négyesi Imre: Artificial intelligence in cyberspace I-AI based cyber-attack capabilities. RED - American Journal Of Research Education And Development, 2. (2019), 31-46. Online: https://pubhtml5.com/lwrb/xykg Fülöp Norbert Attila: Az önvezető autók első gyalogos áldozata. Alapjárat, 2018. március 20. Online: https://alapjarat.hu/nagyvilag-bulvar/nagyvilag/az-onvezeto-autok-elso-gyalogos-aldozata

Gardner, Howard: Frames of Mind - The Theory of Multiple Intelligences. New York, Basic Books, 1983. 
Goyal, Priya et. al.: Self-supervised Pretraining of Visual Features in the Wild. H. n., 2021. Online: http://arxiv.org/pdf/2103.01988v2

Index Holding: Empath in UAE to Measure Happiness. 2018. Online: https://indexholding.ae/empath-in-uae-to-measure-happiness/

Jianhua Tao - Tieniu Tan - Rosalind W. Picard (szerk.): Affective computing and intelligent interaction. Affective computing and intelligent interaction. $1^{\text {st }}$ international conference. Peking, 2005. Online: https://link.springer.com/book/10.1007/11573548

Kunimatsu, Atsushi. et al.: Vector unit architecture for emotion synthesis. IEEE Micro, 20. (2000), 2. 40-47. Online: https://doi.org/10.1109/40.848471

Lee, Jintae - Tosiyasu L. Kunii: Model-based analysis of Hand Posture, IEEE Computer Graphics and Applications, 15. (1995), 5. 77-86. Online: https://doi. org/10.1109/38.403831

Murray, Iain R. - John L. Arnott: Toward the Simulation of Emotion in Synthetic Speech. A Review of the Literature on Human Vocal Emotion. The Journal of the Acoustical Society of America, 93. (1993), 2. 1097-1108. Online: https://doi. org/10.1121/1.405558

Nathanson, Donald L.: Shame and Pride - Affect, Sex, and the Birth of the Self. New York - London, Norton, 1992.

Négyesi Imre: A mesterséges intelligencia katonai felhasználásának társadalmi kérdései. Honvédségi Szemle, 149. (2021), 1. 133-144. Online: https://doi.org/10.35926/ HSZ.2021.1.10

Oatley, Keith - Jennifer M. Jenkins: Érzelmeink. Budapest, Osiris, 2001.

Pat Research: What is Affective computing? Top 15 Affective Computing Companies. 2020. Online: www.predictiveanalyticstoday.com/what-is-affective-computing/

Picard, Rosalind W.: Affective Computing. M.I.T. Media Laboratory Perceptual Computing Section Technical Report. No. 321., 1995. Online: https://affect.media.mit.edu /pdfs/95.picard.pdf

Reding, Dale. F. - Jacqueline Eaton: NATO ST Trends Report 2020-2040, Exploring the SET Edge. Brussels, NATO Science \& Technology Organization, 2020.

Russell, Stuart - Peter Norvig: Mesterséges Intelligencia modern megközelítésben. Budapest, Panem, 2005.

Tomkins, Silvan S.: Affect, imagery, consciousness. New York, Springer, 1962-1963.

Turing, Alan M.: Computing machinery and intelligence. Mind, LIX. (1950), 236. 433460. Online: https://doi.org/10.1093/mind/LIX.236.433

Woods, Dan: Why Big Data Needs Natural Language Generation to Work. Forbes, 2015. július 9. Online: www.forbes.com/sites/danwoods/2015/07/09/why-big-data-needs-natural-language-generation-to-work/?sh=7604e07b156c 